\title{
Systematic review of cognitive impairment and brain insult after mechanical ventilation
}

\author{
Thiago G. Bassi ${ }^{1,2} \mathbb{0}$, Elizabeth C. Rohrs ${ }^{1,3}$ and Steven C. Reynolds ${ }^{1,3^{*}}$
}

\begin{abstract}
We conducted a systematic review following the PRISMA protocol primarily to identify publications that assessed any links between mechanical ventilation (MV) and either cognitive impairment or brain insult, independent of underlying medical conditions. Secondary objectives were to identify possible gaps in the literature that can be used to inform future studies and move toward a better understanding of this complex problem. The preclinical literature suggests that MV is associated with neuroinflammation, cognitive impairment, and brain insult, reporting higher neuroinflammatory markers, greater evidence of brain injury markers, and lower cognitive scores in subjects that were ventilated longer, compared to those ventilated less, and to never-ventilated subjects. The clinical literature suggests an association between MV and delirium, and that delirium in mechanically ventilated patients may be associated with greater likelihood of long-term cognitive impairment; our systematic review found no clinical study that demonstrated a causal link between MV, cognitive dysfunction, and brain insult. More studies should be designed to investigate ventilation-induced brain injury pathways as well as any causative linkage between MV, cognitive impairment, and brain insult.
\end{abstract}

Keywords: Ventilators, Mechanical, Brain injuries, Delirium, Apoptosis, Cognitive impairment

\section{Introduction}

Mechanical ventilation (MV) is considered essential in the Intensive Care Unit (ICU) [1]. While it is undeniable that MV is a crucial life-support tool, it may also cause injury to distal organs, such as the lungs, diaphragm, and brain [2,3]. Ventilation-induced brain injury (VIBI) is well known in neonatology, as a consequence of either hyperoxia or the use of intermittent positive pressure ventilation [4]; in adult patients, the existence of VIBI is still unknown. Preclinical experiments have, however, shown lower cognitive scores in subjects ventilated longer, and that these subjects had greater levels of brain insult, neuroinflammation, and neuronal apoptosis than subjects either mechanically ventilated less, or spontaneously breathing $[5,6]$. Currently, direct links between

\footnotetext{
*Correspondence: sreynolds.md@gmail.com

${ }^{1}$ Simon Fraser University, Burnaby, Canada

Full list of author information is available at the end of the article
}

MV, delirium, cognitive impairment, and neuroinflammation have not been established in the literature.

Delirium is a complex disturbance of consciousness, characterized by acute changes in cognition, a direct consequence of a medical condition, medical treatment, or intoxicating substance [7]. Pathophysiologically, some authors have classified the mechanism that triggers delirium into two distinct categories, direct brain insult (such as hemorrhagic stroke), and aberrant stress response (such as systemic stress induced by MV, sepsis, septic shock, systemic inflammation post-surgery, etc.) [8]. Regardless of the mechanism that triggers delirium, it is postulated that delirium is a result of an imbalance in neurotransmitters, specifically acetylcholine and dopamine, impairing the connection among several brain areas [8-11]. Taking as an example a case-control post-mortem study of deceased ICU patients without direct brain injury, higher levels of inflammatory cells were reported in the hippocampi of deceased patients with delirium than in patients without delirium [5]. This original author(s) and the source, provide a link to the Creative Commons licence, and indicate if changes were made. The images or other third party material in this article are included in the article's Creative Commons licence, unless indicated otherwise in a credit line to the material. If material is not included in the article's Creative Commons licence and your intended use is not permitted by statutory regulation or exceeds the permitted use, you will need to obtain permission directly from the copyright holder. To view a copy of this licence, visit http://creativecommons.org/licenses/by/4.0/. The Creative Commons Public Domain Dedication waiver (http://creativeco mmons.org/publicdomain/zero/1.0/) applies to the data made available in this article, unless otherwise stated in a credit line to the data. 
indicates that when neuroinflammation is triggered, by direct brain insult, aberrant systemic stress response, or some other mechanism, it may be associated with cognitive dysfunction $[5,12,13]$. However, it is likely that there are many factors beyond neuroinflammation that can contribute to cognitive impairment in the ICU, such as medications, immobility, overload of sensory input and lack of adequate sleep [7-10].

We sought to explore the current knowledge in the literature regarding $\mathrm{MV}$, delirium, cognitive impairment, and neuroinflammation, through a systematic review. The primary objective of this systematic review was to identify published papers that assess any link between MV and either cognitive impairment or brain insult, independent of underlying medical conditions. Our secondary objective was to identify possible gaps in the literature that can inform the design of future studies for a better understanding of this complex problem.

\section{Methodology}

This study was conducted following the Preferred Reporting Items for Systematic Review and Meta-Analysis (PRISMA) protocol. Searches were performed by a librarian at the Health Sciences Library at Fraser Health Authority, Royal Columbian Hospital (New Westminster, Canada). Searches were conducted using the following sources: Medline (1946-present), EMBASE (1974-present), Cochrane Database of Systematic Reviews, Cochrane Central Register of Controlled Trials,
Cochrane Methodology Register, and the Database of Abstracts of Reviews and Effects (DARE).

Search strategies were developed based on the search interface, to ensure an appropriate balance between search sensitivity and specificity. The searches were also stratified into two separate concepts, with one search conducted in each database focused on 'preclinical' articles concerning any link between MV and brain insult (Fig. 1a), and a second search focused on 'clinical' articles concerning any link between MV and either cognitive impairment or delirium during the hospital stay and after hospital discharge (Fig. 1b). The preclinical papers were used for consideration of putative mechanisms for brain insult after MV and to identify gaps in the preclinical literature. Articles were limited to prospective and retrospective studies published in English. Keyword, adjacency, wildcard, and subject heading searching were employed in all search strategies to maximize the sensitivity of the search, while publication limits, specific clinical terms, and variants of these were used to increase the specificity of the search results.

Formal searches for articles were run using pre-established keywords (see Additional file 1: Table A), all of which were conducted on January 28, 2020. Subsequently, a screening review of all the articles identified in the formal searches was performed. During the screening review, the abstract of each article was reviewed by the lead author (TGB) to identify articles that clearly met the predetermined exclusion criteria of our study protocol (see Additional file 1: Table B). Duplicate articles a

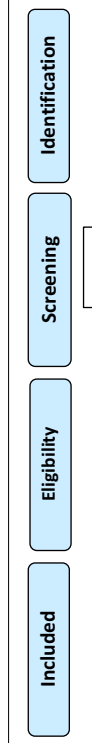

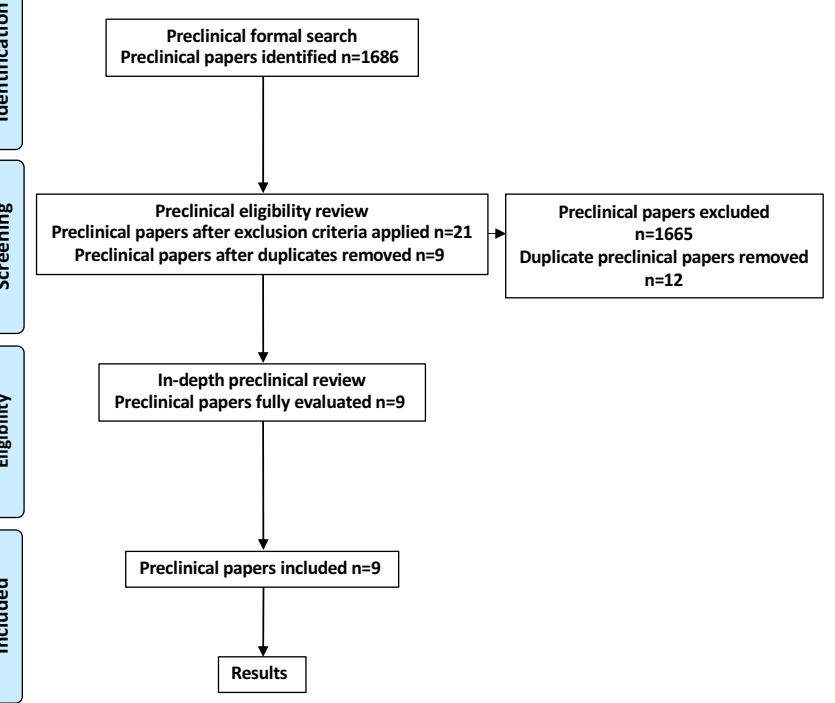

b

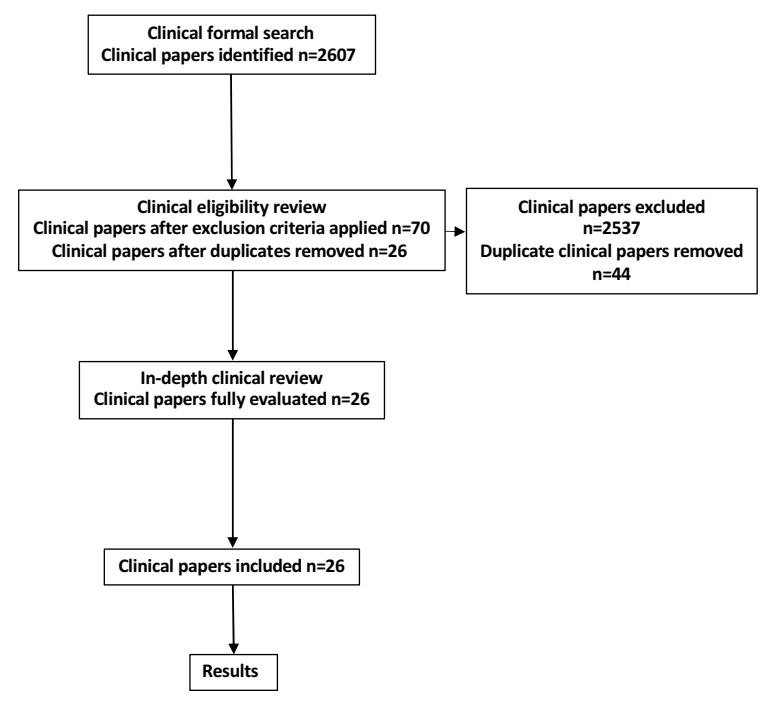

Fig. 1 Systematic review process and results. a Review process for the preclinical papers. b Review process for the clinical papers 
were eliminated as part of the screening review. Articles not eliminated during the screening review then underwent an in-depth review. The full manuscripts selected were evaluated independently by two investigators (TGB and ECR) to reduce the risk of individual bias. The two reviewers (TGB and ECR) used the Downs and Black checklist to assess the quality of each included full manuscript, to compare and reconcile independent evaluations. In the event of significant score discrepancies, a third reviewer (SCR) independently evaluated the paper and served as the adjudicator.

The clinical articles were grouped into three subgroups: papers that reported MV as an independent variable increasing the likelihood for delirium; papers that reported delirium as an independent variable increasing the likelihood for prolonged MV; papers that reported delirium in mechanically ventilated patients increasing the likelihood for long-term cognitive impairment. Odds ratios (OR) were used to calculate the weight and heterogeneity of the manuscripts, using inverse covariance with a random-effects model. Where it was not provided, OR was calculated utilizing data in the papers. $P$ value $<0.1$ for the chi-square test was considered significant. Heterogeneity was evaluated using Higgins metric $\left(I^{2}\right)$, where $I^{2}>75 \%$ was considered significant heterogeneity, $I^{2}$ of $40-74 \%$ was considered moderate heterogeneity, and $I^{2}<39 \%$ was considered no heterogeneity. All statistical analyses were performed using Review Manager software (RevMan, Version 5.4.1, The Cochrane Collaboration, 2020).

\section{Results}

Results from our preclinical and clinical systematic reviews are available in Tables 1 and 2, respectively. Nine preclinical publications and 26 clinical publications were identified. The papers reviewed were produced in five continents: North America 9 (9 clinical, 0 preclinical), South America 3 (3 clinical, 0 preclinical), Europe 12 (5 clinical, 7 preclinical), Asia 9 (7 clinical, 2 preclinical), and Oceania 2 ( 2 clinical, 0 preclinical).

Papers were scored according to the Downs and Black checklist. Of the 35 papers selected, 0 scored 'excellent', 15 (43\%) scored 'good' (9 clinical, 6 preclinical), 18 (51\%) scored 'fair' (clinical 15, preclinical 3), and 2 (6\%) scored 'poor' (both clinical).

All nine preclinical papers measured neuroinflammation, and seven also used brain cellular apoptosis after MV as an outcome (see Table 1). Neuroinflammation was indicated by the elevated presence of microglia, elevated presence of reactive astrocytes, or elevated presence of inflammatory markers. Brain cellular apoptosis was demonstrated by terminal deoxynucleotidyl transferase dUTP nick end labeling (TUNEL) positive cells, by phosphorylation of glycogen synthetase kinase $3 \mathrm{~b}$ (GSK3b), or by cleavage of poly-adenosine-diphosphateribose polymerase-1 (PARP-1). One paper used S100 serum concentration to demonstrate brain insult. Three preclinical papers evaluated cognition after MV, all showing lower cognitive scores in subjects after mechanical ventilation. These three papers used as a measurement of cognitive function either a fear-conditioning test to quantify freezing time, or a validated porcine neurological deficit score.

All 26 clinical papers evaluated delirium during hospitalization as either a primary or secondary variable of interest (Table 2). The most common population studied was ICU patients (24 publications), followed by cardiovascular surgical patients (one publication) and trauma patients (one publication) (Table 2). Thirteen papers included exclusively mechanically ventilated ICU patients in their studies (Table 2). Duration of MV, greater administration of sedative drugs, age $>65$, physical immobility, physical restraint, low APACHE II score, sepsis, hypertension, low level of hemoglobin at hospital admission, smoking, alcohol consumption ( $>2$ drinks daily), and low albumin concentration at ICU admission were risk factors identified either for delirium during hospitalization or for long-term cognitive impairment after hospital discharge.

Twelve clinical papers found that duration of MV is an independent variable associated with a greater likelihood of patients developing delirium during hospitalization. Ten of these twelve papers reported odds ratios ranging from 2.23 to 10.50 , with a pooled odds ratio of 3.42 (Fig. 2). No heterogeneity between the papers was observed with $p=0.55$ for Chi-square, and an $I^{2}$ of $0 \%$. One paper that included only mechanically ventilated patients reported that delirium was diagnosed in 68\% of the patients studied; in those patients diagnosed with delirium, median duration of delirium was 1 day (IQR $1-2)$, and median day of occurrence of delirium was day 5 of MV (IQR 3-7); the authors concluded that prolonged MV is associated with greater likelihood of delirium during hospitalization [43] . Another paper reported that in cancer patients, time of MV increased the likelihood for delirium with an OR of 1.06. This paper reported an average of 8 days of MV for patients with delirium and 2 days of MV for patients without delirium.

Nine clinical papers found that delirium during hospitalization is an independent variable associated with a greater likelihood for a longer duration of MV in ICU patients. Seven of these nine papers reported odds ratios ranging from 1.15 to 10.14 with a pooled odds ratio of 2.06 (Fig. 3). Three of these seven papers did not originally report odds ratio; odds ratios were calculated from data in these three papers. The heterogeneity 
Table 1 Summary of preclinical publications reviewed

\begin{tabular}{|c|c|c|c|c|c|}
\hline Publication & Population & $\begin{array}{l}\text { Mechanical ventilation/ } \\
\text { experimental model }\end{array}$ & $\begin{array}{l}\text { Neuro-inflammation/ } \\
\text { cellular apoptosis } \\
\text { observed after } \\
\text { mechanical ventilation }\end{array}$ & $\begin{array}{l}\text { Low cognitive scores } \\
\text { measured after } \\
\text { mechanical ventilation }\end{array}$ & Brain area(s) studied \\
\hline 2005, Fries et al. [14] & $\begin{array}{l}\text { Pigs } \\
(n=14)\end{array}$ & $\begin{array}{l}\text { Yes/tidal volume } 10 \mathrm{ml} / \\
\mathrm{kg} \text {, lung injury (by } \\
\text { reduced inspired oxy- } \\
\text { gen and by bronchoal- } \\
\text { veolar lavage) }\end{array}$ & Yes & - & Hippocampus \\
\hline 2011, Quilez et al. [15] & $\begin{array}{l}\text { Mice } \\
(n=24)\end{array}$ & $\begin{array}{l}\text { Yes/low tidal volume } \\
(8 \mathrm{ml} / \mathrm{kg}), \text { high tidal } \\
\text { volume (30 ml/kg), } \\
\text { and spontaneously } \\
\text { breathing }\end{array}$ & Yes & - & $\begin{array}{l}\text { Hippocampus, retrosplenial } \\
\text { cortex, thalamus, central } \\
\text { amygdala, paraventricular } \\
\text { nuclei, and supraoptic } \\
\text { nuclei }\end{array}$ \\
\hline $\begin{array}{l}\text { 2011, Bickenbach et al. } \\
\text { [16] }\end{array}$ & $\begin{array}{l}\text { Pigs } \\
(n=10)\end{array}$ & $\begin{array}{l}\text { Yes/tidal volume } 10 \mathrm{ml} / \\
\mathrm{kg} \text {, lung injury (by oleic } \\
\text { acid and by bronchoal- } \\
\text { veolar lavage) }\end{array}$ & Yes & Yes & Hippocampus \\
\hline $\begin{array}{l}\text { 2013, Gonzalez-Lopez } \\
\text { et al. [4] }\end{array}$ & $\begin{array}{r}\text { Mice } \\
(n=127)\end{array}$ & $\begin{array}{l}\text { Yes/low peak inspiratory } \\
\text { pressure }\left(12 \mathrm{cmH}_{2} \mathrm{O}\right) \\
\text { and high peak } \\
\text { inspiratory pressure } \\
\left(2 \mathrm{O} \mathrm{CmH}_{2} \mathrm{O}\right)\end{array}$ & Yes & - & Hippocampus \\
\hline 2015, Chen et al. [5] & $\begin{array}{r}\text { Mice } \\
(n=86)\end{array}$ & $\begin{array}{l}\text { Yes/peak inspiratory pres- } \\
\text { sure }\left(15 \mathrm{cmH}_{2} \mathrm{O}\right)(1 \mathrm{~h} \text {, } \\
3 \mathrm{~h} \text { and } 6 \mathrm{~h} \text {, and spon- } \\
\text { taneously breathing }\end{array}$ & Yes & Yes & Hippocampus \\
\hline 2016, Chen et al. [6] & $\begin{array}{r}\text { Mice } \\
(n=72)\end{array}$ & $\begin{array}{l}\text { Yes/peak inspiratory pres- } \\
\text { sure }\left(15 \mathrm{cmH}_{2} \mathrm{O}\right)(1 \mathrm{~h} \text {, } \\
3 \mathrm{~h} \text { and } 6 \mathrm{~h}) \text {, and spon- } \\
\text { taneously breathing }\end{array}$ & Yes & Yes & Hippocampus \\
\hline 2018, Kamuf et al. [13] & $\begin{array}{r}\text { Pigs } \\
(n=20)\end{array}$ & $\begin{array}{l}\text { s Yes/tidal volume } 7 \mathrm{ml} / \\
\text { ) kg, lung injury (by oleic } \\
\text { acid and by bronchoal- } \\
\text { veolar lavage) }\end{array}$ & Yes & - & Hippocampus \\
\hline $\begin{array}{l}\text { 2019, Lopez-Aguilar et al. } \\
\text { [17] }\end{array}$ & $\begin{array}{r}\text { Pigs } \\
(n=17)\end{array}$ & $\begin{array}{l}\text { s Yes/tidal volume } 10 \mathrm{ml} / \\
\text { ) } \mathrm{kg} \text {, three different head } \\
\text { positions }\left(+30^{\circ},+5^{\circ} \text {, }\right. \\
\left.-30^{\circ}\right)\end{array}$ & Yes & - & Hippocampus \\
\hline $\begin{array}{l}\text { 2019, Gonzalez-Lopez } \\
\text { et al. [18] }\end{array}$ & $\begin{array}{l}\text { Mice } \\
(n=32)\end{array}$ & $\begin{array}{l}\text { Yes/high tidal volume } \\
\text { (20-30 ml/kg) and } \\
\text { spontaneously breath- } \\
\text { ing }\end{array}$ & Yes & - & Hippocampus \\
\hline
\end{tabular}

between the papers was considered substantial with $p<0.0001$ for Chi-square and an $I^{2}$ of $99 \%$. Of the nine papers, one reported that patients with severe delirium were mechanically ventilated for a median of $222 \mathrm{~h}$ (IQR 106-384), patients with moderate delirium were mechanically ventilated for a median of $24 \mathrm{~h}$ (IQR 12-124), and patients with no delirium were mechanically ventilated for a median of $18 \mathrm{~h}$ (IQR 12-41), with statistically significant differences between the groups, $p=0.001$ [22]. One of the nine papers reported that patients with delirium during hospitalization were mechanically ventilated longer than patients without delirium during hospitalization (19.5 days, SD 15.8 vs. 9.3 days, SD 8.8, respectively, $p=0.003$ ) [17].

Five clinical papers found delirium as a predictor of a greater likelihood for chronic cognitive impairment. All five papers included exclusively mechanically ventilated patients. These five papers reported odds ratios ranging from 3.30 to 7.86 with a pooled odds ratio of 3.76 (Fig. 4). One of these five papers did not originally report odds ratio; the odds ratio was calculated from data in that paper. No heterogeneity between the papers was observed, with $p=0.83$ for Chi-square and an $I^{2}$ of $0 \%$. 
Table 2 Summary of clinical publications reviewed

\begin{tabular}{|c|c|c|c|c|c|}
\hline \multirow[t]{2}{*}{ Publication } & \multirow[t]{2}{*}{ Study type } & \multirow[t]{2}{*}{ Number of patients } & \multirow[t]{2}{*}{ Summary of participants } & \multicolumn{2}{|c|}{ Outcomes analyzed } \\
\hline & & & & Delirium & $\begin{array}{l}\text { Long-term } \\
\text { cognitive } \\
\text { impairment }\end{array}$ \\
\hline 2002, Granberg et al. [19] & Prospective cohort study & 19 & $\begin{array}{l}\text { Mechanically ventilated ICU } \\
\text { patients }\end{array}$ & Yes & - \\
\hline 2004, Ely et al. [20] & Prospective cohort study & 275 & $\begin{array}{l}\text { Mechanically ventilated ICU } \\
\text { patients }\end{array}$ & Yes & Yes \\
\hline 2006, Peterson et al. [21] & Prospective cohort study & 375 & ICU patients & Yes & - \\
\hline 2007, Balas et al. [22] & Prospective cohort study & 114 & ICU patients & Yes & - \\
\hline 2008, Lin et al. [23] & Prospective cohort study & 143 & $\begin{array}{l}\text { Mechanically ventilated ICU } \\
\text { patients }\end{array}$ & Yes & - \\
\hline 2009, Rompaey et al. [24] & Prospective cohort study & 523 & ICU patients & Yes & - \\
\hline 2010, Girard et al. [25] & Prospective cohort study & 126 & $\begin{array}{l}\text { Mechanically ventilated ICU } \\
\text { patients }\end{array}$ & Yes & Yes \\
\hline 2010, Tsuruta et al. [26] & Prospective cohort study & 172 & ICU patients & Yes & - \\
\hline 2010, Shehabi et al. [27] & Prospective cohort study & 354 & $\begin{array}{l}\text { Mechanically ventilated ICU } \\
\text { patients }\end{array}$ & Yes & - \\
\hline 2012, Sharma et al. [28] & Prospective cohort study & 140 & ICU patients & Yes & - \\
\hline 2013, Haas et al. [29] & Prospective cohort study & 1216 & ICU patients & Yes & Yes \\
\hline 2013, Norkiene et al. [30] & Prospective cohort study & 87 & Cardiovascular surgery patients & Yes & - \\
\hline 2014, Brummel et al. [31] & Prospective cohort study & 126 & $\begin{array}{l}\text { Mechanically ventilated ICU } \\
\text { patients }\end{array}$ & Yes & Yes \\
\hline 2014, Tsuruta et al. [32] & Prospective cohort study & 180 & $\begin{array}{l}\text { Mechanically ventilated ICU } \\
\text { patients }\end{array}$ & Yes & Yes \\
\hline 2014, Connor et al. [33] & Prospective cohort study & 80 & $\begin{array}{l}\text { Mechanically ventilated ICU } \\
\text { patients }\end{array}$ & Yes & - \\
\hline 2015, Mehta et al. [34] & Prospective cohort study & 430 & $\begin{array}{l}\text { Mechanically ventilated ICU } \\
\text { patients }\end{array}$ & Yes & Yes \\
\hline 2015, Hsieh et al. [35] & Prospective cohort study & 564 & $\begin{array}{l}\text { Mechanically ventilated ICU } \\
\text { patients }\end{array}$ & Yes & - \\
\hline 2016, Almeida et al. [36] & Prospective cohort study & 113 & ICU patients & Yes & - \\
\hline 2017, Chen et al. [37] & Prospective cohort study & 620 & ICU patients & Yes & - \\
\hline 2017, Mesa et al. [38] & Prospective cohort study & 230 & $\begin{array}{l}\text { Mechanically ventilated ICU } \\
\text { patients }\end{array}$ & Yes & - \\
\hline 2017, Rueden et al. [39] & Prospective cohort study & 215 & Trauma patients & Yes & - \\
\hline 2018, Shehabi et al. [40] & $\begin{array}{l}\text { Prospective cohort multicenter } \\
\text { study }\end{array}$ & 710 & $\begin{array}{l}\text { Mechanically ventilated ICU } \\
\text { patients }\end{array}$ & Yes & - \\
\hline 2018, Singh et al. [41] & Retrospective cohort study & 67,333 & ICU patients & Yes & - \\
\hline 2018, Sanchez-Hurtado et al. [42] & Prospective cohort study & 109 & ICU/cancer patients & Yes & - \\
\hline 2018, Mitchell et al. [43] & Prospective cohort study & 148 & $\begin{array}{l}\text { Mechanically ventilated ICU } \\
\text { patients }\end{array}$ & Yes & Yes \\
\hline 2019, Torres-Contreras et al. [44] & Prospective cohort study & 134 & ICU patients & Yes & - \\
\hline
\end{tabular}

Another paper reported that more than 8 days of MV increased the likelihood for long-term cognitive impairment two years after hospitalization, with a risk ratio of 1.48 [24].

\section{Discussion}

Our preclinical search found evidence that $M V$ is a contributing factor that can induce brain insult, either by inducing systemic inflammation or by changing the vagal signal, associated with neuroinflammation and neuronal death [3, 5, 6, 13-18]. Moreover, all preclinical studies reported in our systematic review found brain insult after MV [3, 5, 6, 13-18]; three preclinical studies found an association between the brain insult and worse cognitive scores in prolonged mechanically ventilated subjects in comparison with either neverventilated subjects or short-term mechanically ventilated subjects $[3,5,6]$. Although these studies were not 


\section{Prolonged MV and increased likelihood of delirium}

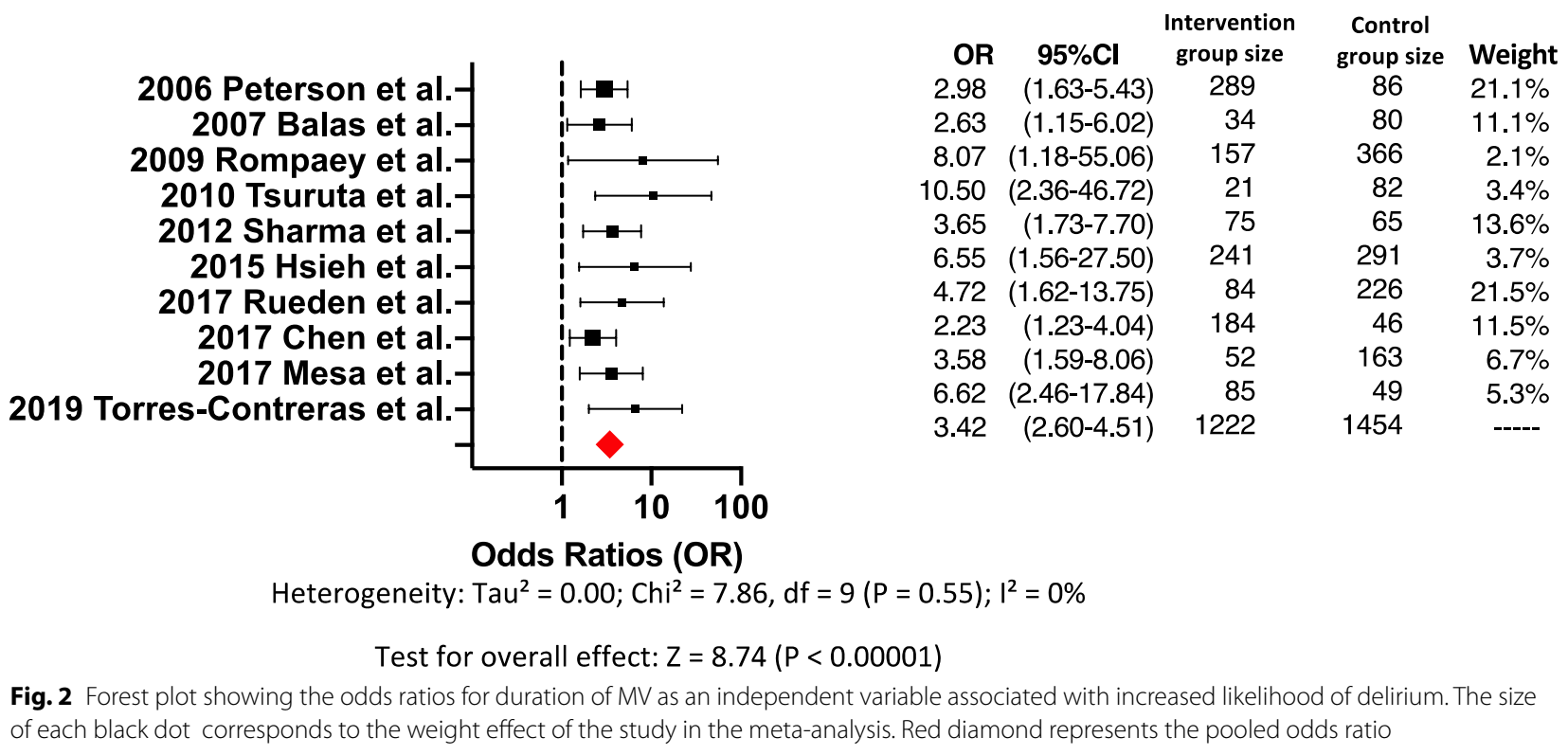

\section{Delirium and increased likelihood of prolonged MV}

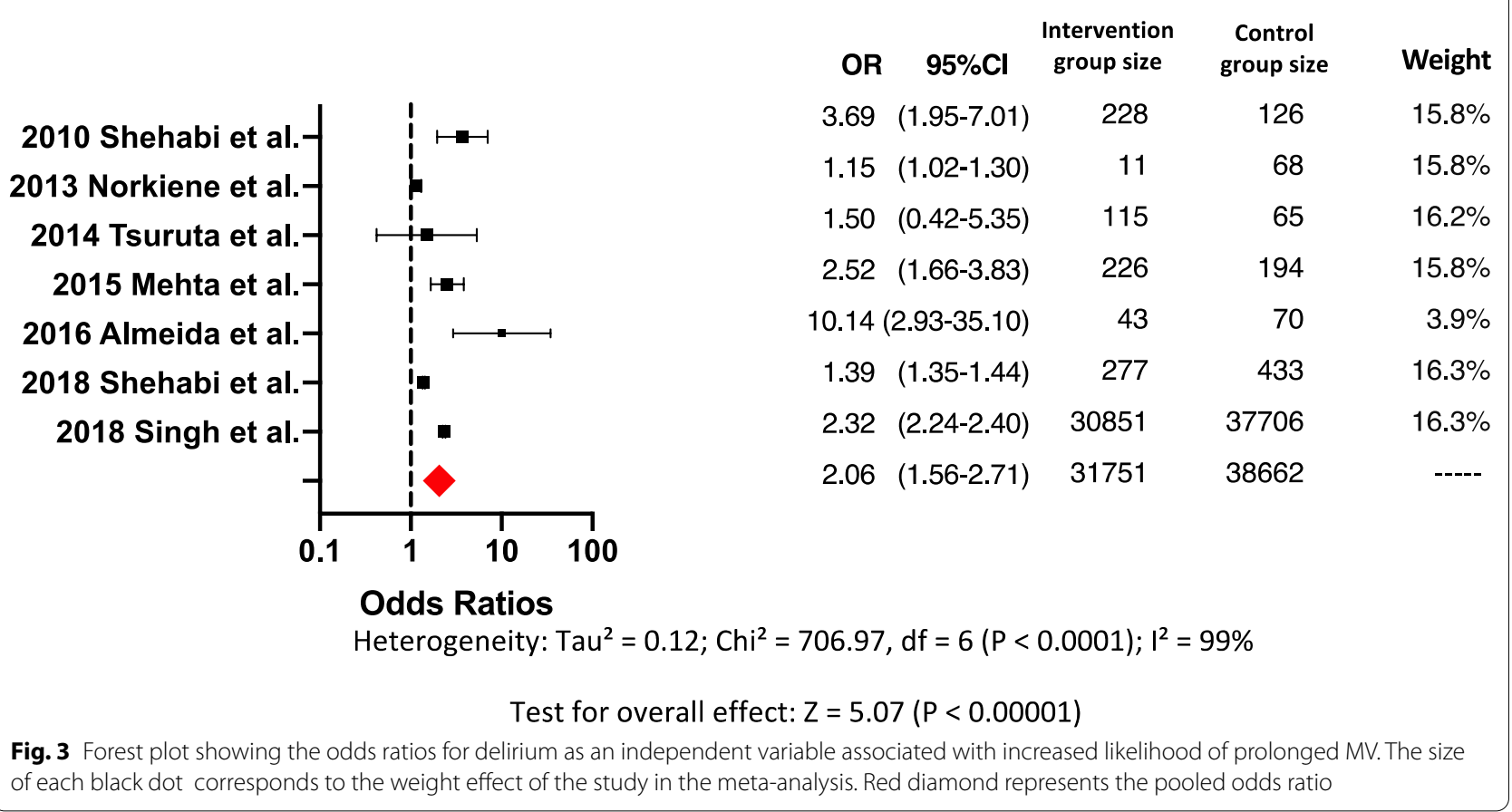

able to entirely control for factors that co-varied with $\mathrm{MV}$, such as sedation or immobility, there is a consistent signal across all studies showing an association between MV and brain insult. High levels of pro-apoptotic proteins and elevated levels of inflammatory cells in the brain after MV were reported in nine preclinical 


\section{Delirium in MV patients and increased likelihood of long-term cognitive impairment}

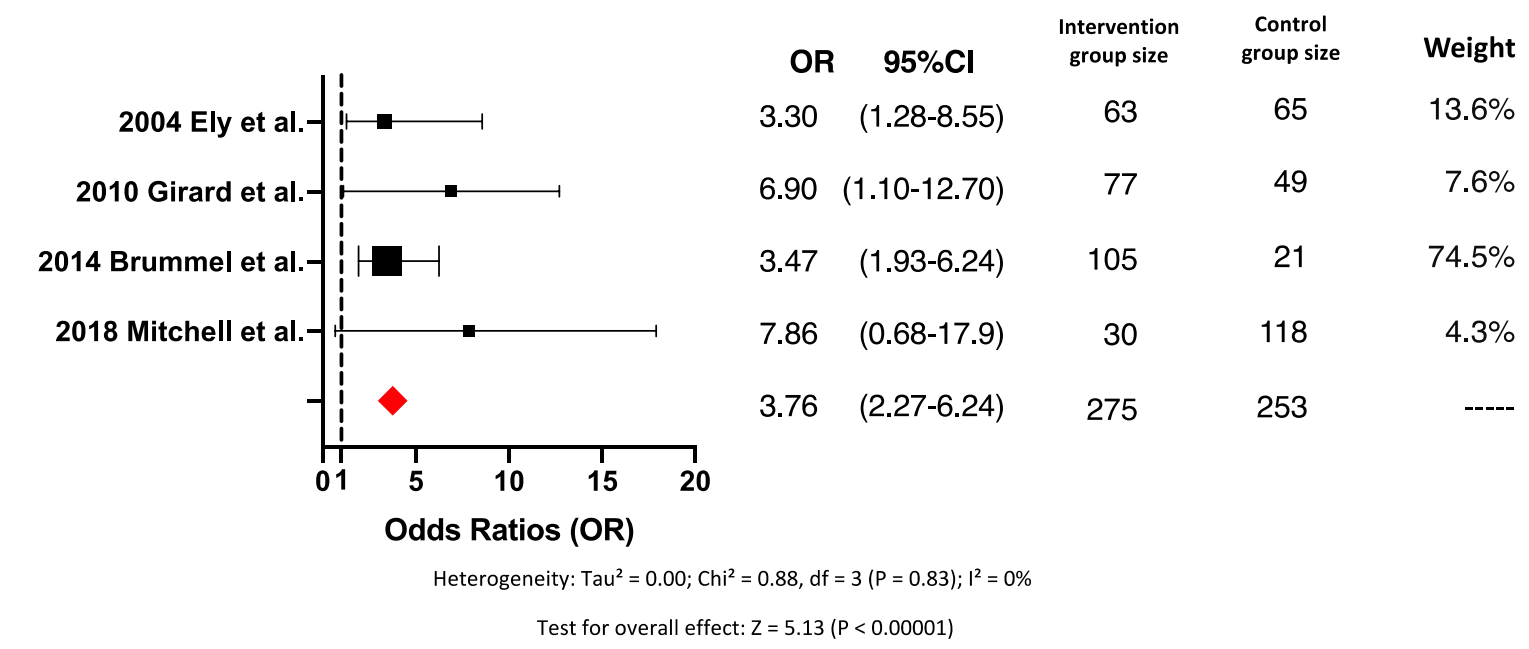

Fig. 4 Forest plot showing the odds ratios for delirium during MV as an independent variable associated with increased likelihood of long-term cognitive impairment. The size of each black dot corresponds to the weight effect of the study in the meta-analysis. Red diamond represents the pooled odds ratio

papers identified in our systematic review (see Table 1 ) $[3,5,6,13-18]$.

Preclinical considerations regarding putative mechanisms for cognitive impairment after MV

According to our preclinical search, the mechanism of action for brain insult after MV has two postulated pathways, inflammation and neural signaling [3, 5, 6, 13-18].

\section{Inflammatory pathway}

Six preclinical papers investigated the inflammatory pathway for brain insult after MV [5, 6, 13-15]. In the postulated inflammatory pathway for VIBI, MV creates a pro-inflammatory systemic state that triggers neuroinflammation in the brain $[5,6,15]$. Three preclinical papers found that subjects mechanically ventilated for a longer duration $(6 \mathrm{~h})$ had greater serum inflammatory markers and greater neuroinflammation either than subjects ventilated for a shorter duration $(1 \mathrm{~h})$ or than subjects that were never ventilated $[5,6,15]$. One study demonstrated that the activation of pulmonary tolllike receptor- 4 was responsible for the initiation of the inflammatory cascade since toll-like receptor-4 knockout subjects did not demonstrate the neuroinflammatory effects after MV, even when ventilated longer $(6 \mathrm{~h})$ [6]. This same study showed that toll-like receptor- 4 knockout subjects after six hours of MV had cognitive scores (freezing time and locomotor activity) similar to the never-ventilated group [6]. The inflammatory hypothesis was challenged by one study that investigated the levels of inflammatory and apoptotic markers in the hippocampus after inducing lung injury [13]. This study showed that mechanically ventilated pigs without lung injury and mechanically ventilated pigs with lung injury showed similar levels of inflammatory and apoptotic brain markers, thereby concluding that the inflammatory process induced by lung injury was not the factor responsible for the hippocampus insult, but rather MV itself [13].

\section{Neural signaling pathway}

Two preclinical papers investigated the neural pathway for brain insult after MV [3, 18]. It has been proposed that the neural signal coming from the vagus nerve triggers neuroinflammation and brain injury during MV [3]. In the postulated neural pathway for VIBI, the vagal afferent signal changes as a result of cyclical alveolar stretch due to positive-pressure MV, leading to activation of pulmonary transient receptor potential vanilloid channel type 4 (TRPV4), and consequently to a reduction in gene expression of pulmonary TRPV4 and purinergic type 2X receptors [18]. According to the authors, the pulmonary TRPV4 activation would lead to a hippocampal overexpression of type 2 dopamine receptors, which would deactivate the $\mathrm{B} /$ glycogen synthetase kinase $3 \beta$ (Akt/GSK3ß), initiating the apoptotic cascade [18]. In order to demonstrate the hypothesized neural signaling pathway for VIBI, researchers compared hippocampal 
apoptosis in mechanically ventilated subjects with chemical vagotomy, with surgical vagotomy, and without vagotomy, and in never-ventilated subjects $[3,18]$. It was found that vagotomy, either chemical or surgical, mitigated ventilation-induced brain injury [3]. The vagotomised groups had levels of hippocampal apoptosis similar to the neverventilated group, resulting in the conclusion that the vagal signal triggered the brain injury after the initiation of MV [3, 18]. Moreover, to demonstrate that dopamine overexpression was part of the mechanism that triggered cellular apoptosis, the authors showed that the administration of a dopamine blocker mitigated the brain insult after MV in a group of subjects without vagotomy, under the same conditions that led to brain insult in mechanically ventilated subjects [3].

\section{Cognitive impairment and MV (preclinical)}

Cognition after MV was evaluated in three preclinical studies identified in our search $[5,6,14]$. Two papers demonstrated that experimental mice undergoing six hours of MV had lower cognitive scores at three days post-extubation than either one-hour-MV mice or neverventilated mice $[5,6]$. One paper showed that a possible mechanism for cognitive impairment was the overexpression of TLR4 receptors in the lungs and in the brain, triggering inflammation and promoting the proliferation of pro-inflammatory microglia and reactive astrocytes, impairing brain function [6]. To demonstrate the role of neuroinflammation in cognitive impairment, the authors showed that TLR4-knockout subjects undergoing prolonged MV had similar microglia, reactive astrocytes, systemic inflammatory markers, and cognitive scores to control subjects [6]. Moreover, in prolonged mechanically ventilated subjects, neuroinflammation resulted in synapse degeneration, cytochrome c release, cleaved caspase-3, and cleaved PARP-1 activation, which may have consequently led to the worse cognitive scores observed in this group compared to the control group [5]. The effects of inflammation on cognition were assessed in one paper [14]; mechanically ventilated pigs with hypoxemia caused by lung injury due to surfactant depletion had worse cognitive performance 5 days after extubation than mechanically ventilated pigs with hypoxemia caused by reduction in inspired oxygen concentration [14]. The authors concluded that the inflammatory process may be a key factor for cognitive impairment in pigs [14].

\section{The connection between tidal volume and brain activity}

The connection between hippocampal activity and the breathing cycle was demonstrated by one preclinical study [18]. This study used functional MRI to analyze hippocampus activity, comparing higher-tidal-volume subjects with lower-tidal-volume subjects [18]. The authors demonstrated that higher-tidal-volume MV resulted in more hippocampus activity, and that higher activation of the hippocampus during high-tidal-volume MV was correlated with more tissue injury [18]. In addition to the hippocampus, other brain areas were also studied during MV. Greater numbers of c-Fos-positive cells were observed in the retrosplenial cortex and in the thalamus of high-tidal-volume subjects when compared to low-tidal-volume subjects [16]. C-Fos is a neuronal activity marker expressed after neuronal depolarization [40]. Neurons express c-Fos protein proportionally to the stimulus applied, either chemical or electrical [40]. In low-tidal-volume subjects, c-Fos was expressed at low levels, while in high-tidal-volume subjects, this neuronal activity marker was expressed at high levels [16]. The authors stated that the tidal volume used during MV may have led to pathological neuronal activity in the retrosplenial cortex and in the thalamus, since the high-tidalvolume group expressed greater c-Fos protein in these brain areas than the low-tidal-volume group [16]; also, the brain insult observed was proportional to the tidal volume delivered, suggesting a potential iatrogenic effect of MV on the brain [16].

\section{Current clinical literature perspective on cognitive impairment and MV}

Mechanically ventilated patients are frequently sedated and typically have worse health conditions than patients who are never ventilated $[19,21,22,35,37,45]$. It is extremely challenging to show any causative linkage between MV, delirium and cognitive impairment. This is in part because the MV "package" has multiple inseparable variables, such as sedation and physical immobility. For instance, mechanically ventilated patients receive more drugs and are more physically inactive than spontaneously breathing patients $[19,21,22,35,37,45]$. The greater use of drugs and greater prevalence of physical inactivity in mechanically ventilated patients might be factors that also affect the health of the patient, worsening the cognitive functions [19, 21, 22, 35, 37, 45]. Additionally, widespread use of MV in a heterogeneous patient population makes the isolation of causal relationships difficult. Although multiple risk factors have been identified for delirium and long-term cognitive impairment in our systematic review, papers that utilized multivariate analysis have consistently shown either duration of MV as an independent variable associated with delirium, or delirium as an independent variable associated with prolonged duration of MV [16, 17, 20-29, 45]. Moreover, delirium in mechanically ventilated patients was correlated with a greater likelihood for long-term cognitive impairment than mechanically ventilated patients without delirium $[20,24,26,30,38$, 
42]. The papers analyzed in this systematic review did not establish a direct causal link between duration of MV, delirium, and long-term cognitive impairment; however, our review identified important gaps in the literature that can be used in designing future studies.

\section{Duration of $\mathrm{MV}$ as an independent variable for developing delirium during hospitalization}

Our systematic review identified twelve papers that showed an association between longer duration of MV and a greater likelihood of a patient developing delirium during hospitalization, when compared either with patients mechanically ventilated fewer days, or with spontaneously breathing patients [19-21, 24, 30, 32, 35, 36, 43-45]. For instance, ten papers found odds ratios between 1.06 and 10.50 for a greater likelihood that a patient develops delirium during hospitalization when the duration of MV is longer than one day (Fig. 2) [19-21, $24,32,35,36,43,44]$. Ten of these twelve papers showed a dose-dependent aspect, as, regardless of comorbidities, the longer the duration of MV, the greater the likelihood of delirium with a pooled odds ratio of 3.42 [19-21, 24, $30,32,35,36,43,44]$. No heterogeneity was observed after analysis of these ten papers. The homogeneity of these papers may be interpreted as a strong and consistent signal indicating that increased duration of MV increases the likelihood for delirium [19-21, 24, 30, 32, $35,36,43,44]$.

\section{Delirium during hospitalization as an independent variable for prolonged duration of $\mathrm{MV}$}

Although multiple risk factors may prolong the days on MV in critically ill patients, delirium has been commonly identified as one of those risk factors for prolonged duration of MV [22, 25-27, 29, 31, 35, 36, 41]. Nine clinical papers found an association between delirium and prolonged $\mathrm{MV}$, of which seven calculated the odds ratio and two calculated how much longer, either in days or hours, delirium prolonged MV [22, 25-27, 29, 31, 35, 36, 41]. Seven of nine papers identified by our systematic review showed that patients with delirium during hospitalization have greater likelihood to be mechanically ventilated longer than patients without delirium during hospitalization with a pooled odds ratio of 2.06 (Fig. 3) [22, 25, 27, $29,31,35,36]$. Patients who were diagnosed with delirium during hospitalization underwent between seven and ten more days on $\mathrm{MV}$, compared with patients who were not diagnosed with delirium $[35,41]$. Although a positive correlation between delirium and MV has been shown in our systematic review, the clinical literature has not reported any causative linkage between them [22, $25,27,29,31,35,36]$. Our systematic review indicates a high heterogeneity for the seven papers selected in this subgroup analysis. This may be a consequence of a small standard error for each of the studies included in the analysis. Another reason may be the high degree of heterogeneity typically observed in the ICU patient population studied resulting in a wide range of results reported. Different methods to measure the outcomes, different study designs and different types of interventions may also have affected heterogeneity. However, all studies included in this part of our analysis investigated delirium as an independent factor for prolonged MV, showing ORs higher than 1 . Regardless of the heterogeneity of the papers analyzed, it seems that when an ICU patient develops delirium it increases the likelihood for prolonged MV.

\section{Delirium in mechanically ventilated patients associated with increased likelihood of long-term cognitive impairment}

Delirium in mechanically ventilated patients was also found to be one risk factor associated with long-term cognitive impairment [20, 26, 38, 42]. Four papers included only mechanically ventilated patients, reported that patients who developed delirium during hospitalization had a greater likelihood of showing long-term cognitive dysfunction than patients who did not develop delirium during hospitalization, reporting odds ratios ranging from 3.20 to 7.86 with a pooled odds ratio of 3.76 (Fig. 4) [20, 26, 38, 42]. Moreover, in mechanically ventilated patients with delirium during hospitalization, long-term cognitive deficits were subsequently identified up to seven times as often, compared to mechanically ventilated patients without delirium during hospitalization, although this may be due to underlying predisposition rather than MV itself [20, 26, 38, 42]. These four papers reported that more than 2 days of MV is associated with up to four times greater likelihood of developing acute cognitive impairment, and that those patients who develop acute cognitive impairment have up to twice the risk of persistent chronic cognitive impairment $[20,26,30,38,42]$. The residual impact of delirium in mechanically ventilated patients was detected up to 6 years after hospital discharge [20, 42]. The lack of heterogeneity observed may be an indicator that when a mechanically ventilated patient develops delirium it considerably increases the likelihood for long-term cognitive impairment.

\section{Gaps in the current literature and the need for future studies}

Our systematic review identified some notable gaps in the scientific literature. Firstly, we note that none of the identified preclinical or clinical papers investigated ventilatory strategies, focusing, for example, either on ventilation power or on driving pressure, and their effects on 
cognitive outcomes. Three preclinical papers investigated alternative methods, either pharmacological or surgical, to prevent VIBI $[3,6,18]$. Dopamine receptors, TLR-4 receptors and TRPV4 receptors are pharmacological targets that, when blocked, were reported to prevent VIBI. In addition, either chemical or surgical vagotomy also showed reduced hippocampal apoptosis and inflammation, even during high-tidal-volume MV; however, vagotomy is not a viable solution in clinical practice $[3,6,18]$. Secondly, only nine preclinical publications were identified in our search; this suggests that more work is needed in this area in order to better understand the effects of MV on the brain $[3,5,6,13-18]$. Notably, all nine preclinical studies used injurious (high-tidal-volume or high peak-inspiratory-pressure) ventilation; this observation raises the question as to whether the effects of lung-protective MV on the brain should also be studied preclinically $[3,5,6,13-18]$. Thirdly, of the preclinical studies identified, three observed greater neuronal activity during MV; this finding should be more thoroughly investigated in future studies to better understand whether the changes in the neurophysiology during MV result in harmful effects on the brain [16]. Fourthly, it is important to recognize that many other factors are linked to delirium and cognitive impairment in critically ill patients; our systematic review found that MV may be associated with delirium, but no study showed any causative linkage between MV and delirium. Considering these observations, more preclinical studies should be designed focusing on the investigation of potential causal links between MV, brain insult, and cognitive impairment, and more clinical studies should be designed to investigate the possibility of causal links between MV, brain insult, and delirium and cognitive impairment, controlling for potentially confounding factors that co-vary with duration of MV, such as sedation and immobility.

\section{Conclusion}

This systematic review showed an association between MV and acute cognitive impairment.

In our search, preclinical papers showed acute cognitive impairment after $\mathrm{MV}$, describing greater neuroinflammation and lower cognitive scores in subjects with longer duration of MV.

Clinically, increased duration of MV may be associated with a greater risk for delirium during hospitalization. Moreover, delirium in mechanically ventilated patients may be associated with long-term cognitive impairment, and residual cognitive impairment can be observed up to 6 years after hospital discharge.

Preclinical and clinical studies that investigate the relationship between different ventilation strategies and cognitive impairment have not been reported. Conducting such studies may be worthwhile in order to better understand cognitive impairment after MV.

While our systematic review identified gaps in the literature that can be considered when designing future studies to further evaluate the relationships between $\mathrm{MV}$, brain insult, and cognitive impairment, our findings confirm that future work is needed to identify any causal links between them.

\section{Supplementary Information}

The online version contains supplementary material available at https://doi. org/10.1186/s13054-021-03521-9.

Additional file 1. Additional information about the systematic review, such as keywords used for the search and exclusion criteria used.

\section{Acknowledgements}

The authors would like to acknowledge and thank the following people for their efforts and assistance in completing this body of work: Matt Gani, Dawn Bitz, Doug Evans, Viral Thakkar, Suzette Williams, Samar Hejazi, Teresa Nelson and Brooke Ballantyne Scott.

\section{Authors' contributions}

TGB was responsible for hypothesis generation. TGB and SCR were responsible for the conception of this study. TGB, SCR, and ECR contributed to study design and data interpretation. TGB, SCR, and ECR were responsible for writing the article. TGB and ECR performed data acquisition. TGB, ECR, and SCR conducted data analysis. All authors have agreed with the final version of the manuscript before submission. All authors read and approved the final manuscript.

\section{Funding}

This study was supported by grants from Lungpacer Medical, Inc., The Royal Columbian Hospital Foundation, TB Vets and MITACS.

\section{Availability of data and materials}

The datasets used and/or analyzed during the current study are available from the corresponding author on reasonable request.

\section{Declarations}

Ethical approval and consent to participate

Not applicable.

\section{Consent for publication}

Not applicable.

\section{Competing interests}

ECR and SCR have received consulting fees from Lungpacer Medical, Inc. TGB is an employee of Lungpacer Medical, Inc. SCR is listed on a patent for Lungpacer Medical, Inc.

\section{Author details \\ ${ }^{1}$ Simon Fraser University, Burnaby, Canada. ${ }^{2}$ Lungpacer Medical Inc, Vancouver, Canada. ${ }^{3}$ Royal Columbian Hospital, Fraser Health Authority, 260} Sherbrooke Street, New Westminster, BC V3L 3M2, Canada.

Received: 14 November 2020 Accepted: 1 March 2021

Published online: 10 March 2021

\section{References}

1. Reynolds S, Ebner A, Meffen T, et al. Diaphragm activation in ventilated patients using a novel transvenous phrenic nerve pacing catheter. Crit 
Care Med. 2017;45(7):e691-4. https://doi.org/10.1097/CCM.0000000000 002366.

2. Reynolds SC, Meyyappan R, Thakkar V, et al. Mitigation of ventilatorinduced diaphragm atrophy by transvenous phrenic nerve stimulation. Am J Respir Crit Care Med. 2017;195(3):339-48. https://doi.org/10.1164/ rccm.201502-03630C.

3. González-López A, López-Alonso I, Aguirre A, et al. Mechanical ventilation triggers hippocampal apoptosis by vagal and dopaminergic pathways. Am J Respir Crit Care Med. 2013;188(6):693-702. https://doi.org/10.1164/ rccm.201304-06910C.

4. Barton SK, Tolcos M, Miller SL, et al. Ventilation-induced brain injury in preterm neonates: a review of potential therapies. Neonatology. 2016;110(2):155-62. https://doi.org/10.1159/000444918.

5. Chen C, Zhang Z, Chen T, Peng M, Xu X, Wang Y. Prolonged mechanical ventilation-induced neuroinflammation affects postoperative memory dysfunction in surgical mice. Crit Care. 2015;19(1):1-12. https://doi. org/10.1186/s13054-015-0882-0

6. Chen T, Chen C, Zhang Z, Zou Y, Peng M, Wang Y. Toll-like receptor 4 knockout ameliorates neuroinflammation due to lung-brain interaction in mechanically ventilated mice. Brain Behav Immun. 2016:56:42-55. https://doi.org/10.1016/j.bbi.2016.04.004.

7. van Munster BC, Aronica E, Zwinderman AH, Eikelenboom P, Cunningham C, de Rooij SEJ. Neuroinflammation in delirium: a postmortem case-control study. Rejuvenation Res. 2011;14(6):615-22. https://doi. org/10.1089/rej.2011.1185.

8. Sasannejad C, Ely EW, Lahiri S. Long-term cognitive impairment after acute respiratory distress syndrome: a review of clinical impact and pathophysiological mechanisms. Crit Care. 2019;23(1):1-12. https://doi. org/10.1186/s13054-019-2626-z.

9. Alsop DC, et al. The role of neuroimaging in elucidating delirium pathophysiology. J Gerontol Med Sci. 2006;61 A(12):1287-93. https://doi. org/10.1016/j.neuropharm.2017.09.032.

10. Morandi A, McCurley J, Vasilevskis EE, et al. Tools to detect delirium superimposed on dementia: a systematic review. J Am Geriatr Soc. 2012;60(11):2005-13. https://doi.org/10.1111/j.1532-5415.2012.04199.x.

11. Janz DR, Abel TW, Jackson JC, Gunther ML, Heckers S, Ely EW. Brain autopsy findings in intensive care unit patients previously suffering from delirium: a pilot study. J Crit Care. 2010;25(3):538.e7-538.e12. https://doi. org/10.1016/j.jcrc.2010.05.004

12. van Munster $B C$, et al. Delirium: a synthesis of current knowledge. Clin Med J R Coll Phys Lond. 2014;14(2):192-5. https://doi.org/10.7861/clinm edicine.14-4-454a.

13. Kamuf J, Garcia-Bardon A, Ziebart A, et al. Lung injury does not aggravate mechanical ventilation-induced early cerebral inflammation or apoptosis in an animal model. PLoS ONE. 2018. https://doi.org/10.1371/journ al.pone.0202131.

14. Bickenbach J, Biener I, Czaplik M, et al. Neurological outcome after experimental lung injury. Respir Physiol Neurobiol. 2011;179(2-3):174-80. https ://doi.org/10.1016/j.resp.2011.08.003.

15. Fries M, Bickenbach J, Henzler D, et al. S-100 protein and neurohistopathologic changes in a porcine model of acute lung injury. Anesthesiology. 2005;102(4):761-7. https://doi.org/10.1097/00000542-20050 4000-00011.

16. Quilez M, Fuster G, Villar J, Flores C, Octavi M-S, Lluís B, López-Aguilar J. Injurious mechanical ventilation affects neuronal activation in ventilated rats. Crit Care. 2011;15(3):R124. https://doi.org/10.1186/cc10230.

17. López-Aguilar J, Bassi GL, Quílez ME, et al. Hippocampal damage during mechanical ventilation in trendelenburg position: a secondary analysis of an experimental study on the prevention of ventilator-associated pneumonia. Shock. 2019;52(1):75-82. https://doi.org/10.1097/SHK.00000 00000001237.

18. González-López A, López-Alonso I, Pickerodt PA, et al. Lung purinoceptor activation triggers ventilator-induced brain injury. Crit Care Med. 2019:47(11):e911-8. https://doi.org/10.1097/CCM.0000000000003977.

19. Van Rompaey B, Elseviers MM, Schuurmans MJ, Shortridge-Baggett LM, Truijen S, Bossaert L. Risk factors for delirium in intensive care patients: a prospective cohort study. Crit Care. 2009;13(3):1-12. https://doi. org/10.1186/cc7892.

20. Tsuruta R, Nakahara T, Miyauchi T, et al. Prevalence and associated factors for delirium in critically ill patients at a Japanese intensive care unit. Gen
Hosp Psychiatry. 2010;32(6):607-11. https://doi.org/10.1016/j.genhosppsy ch.2010.09.001.

21. Girard TD, Jackson JC, Pandharipande PP, et al. Delirium as a predictor of long-term cognitive impairment in survivors of critical illness. Crit Care Med. 2010;38(7):1513-20. https://doi.org/10.1097/CCM.0b013e3181 e47be1.

22. Shehabi Y, Riker RR, Bokesch PM, Wisemandle W, Shintani A, Ely EW. Delirium duration and mortality in lightly sedated, mechanically ventilated intensive care patients. Crit Care Med. 2010;38(12):2311-8.

23. Sharma A, Malhotra S, Grover S, Jindal SK. Incidence, prevalence, risk factor and outcome of delirium in intensive care unit: a study from India. Gen Hosp Psychiatry. 2012;34(6):639-46. https://doi.org/10.1016/j.genho sppsych.2012.06.009.

24. Haas JS, Teixeira C, Cabral CR, et al. Factors influencing physical functional status in intensive care unit survivors two years after discharge. BMC Anesthesiol. 2013;13:1-9. https://doi.org/10.1186/1471-2253-13-11.

25. Norkiene I, et al. Incidence and risk factors of early delirium after cardiac surgery. Biomed Res Int. 2013;17(5):797. https://doi.org/10.1093/icvts/ ivt413.

26. Brummel NE, Jackson JC, Pandharipande PP, et al. Delirium in the ICU and subsequent long-term disability among survivors of mechanical ventilation. Crit Care Med. 2014;42(2):369-77. https://doi.org/10.1097/ CCM.0b013e3182a645bd.

27. Tsuruta R, Oda Y, Shintani A, et al. Delirium and coma evaluated in mechanically ventilated patients in the intensive care unit in Japan: a multi-institutional prospective observational study. J Crit Care. 2014;29(3):472.e1-472.e5. https://doi.org/10.1016/j.jcrc.2014.01.021.

28. O'Connor H, Al-Qadheeb NS, White AC, Thaker V, Devlin JW. Agitation during prolonged mechanical ventilation at a long-term acute care hospital: risk factors, treatments, and outcomes. J Intensive Care Med. 2014:29(4):218-24. https://doi.org/10.1177/0885066613486738.

29. Mehta S, Cook D, Devlin JW, et al. Prevalence, risk factors, and outcomes of delirium in mechanically ventilated adults. Crit Care Med. 2015;43(3):557-66. https://doi.org/10.1097/CCM.0000000000000727.

30. Hsieh SJ, Soto GJ, Hope AA, Ponea A, Gong MN. The association between acute respiratory distress syndrome, delirium, and in-hospital mortality in intensive care unit patients. Am J Respir Crit Care Med. 2015;191(1):71-8. https://doi.org/10.1164/rccm.201409-16900C

31. De Almeida TML, De Azevedo LCP, Nosé PMG, De Freitas FGR, Machado FR. Risk factors for agitation in critically ill patients. Rev Bras Ter Intensiva. 2016;28(4):413-9. https://doi.org/10.5935/0103-507X.20160074.

32. Chen Y, Du H, Wei BH, Chang XN, Dong CM. Development and validation of risk-stratification delirium prediction model for critically ill patients. Medicine (United States). 2017. https://doi.org/10.1097/MD.0000000000 007543.

33. Mesa P, Previgliano IJ, Altez S, et al. Delirium in a Latin American intensive care unit. A prospective cohort study of mechanically ventilated patients. Rev Bras Ter Intensiva. 2017;29(3):337-45. https://doi.org/10.5935/0103507X.20170058.

34. Rueden KTV, Wallizer B, Thurman P, et al. Delirium in trauma patients: prevalence and predictors. Crit Care Nurse. 2017;37(1):40-8. https://doi. org/10.4037/ccn2017373.

35. Shehabi Y, Bellomo R, Kadiman $\mathrm{S}$, et al. Sedation intensity in the first 48 hours of mechanical ventilation and 180-day mortality: a multinational prospective longitudinal cohort study. Crit Care Med. 2018:46(6):850-9. https://doi.org/10.1097/CCM.0000000000003071.

36. Singh TD, O'Horo JC, Gajic O, et al. Risk factors and outcomes of critically ill patients with acute brain failure: a novel end point. J Crit Care. 2018;43:42-7. https://doi.org/10.1016/j.jcrc.2017.08.028.

37. Sánchez-Hurtado LA, Hernández-Sánchez N, Del Moral-Armengol M, et al. Incidence of delirium in critically ill cancer patients. Pain Res Manag. 2018. https://doi.org/10.1155/2018/4193275.

38. Mitchell ML, Shum DHK, Mihala G, Murfield JE, Aitken LM. Long-term cognitive impairment and delirium in intensive care: a prospective cohort study. Aust Crit Care. 2018;31(4):204-11. https://doi.org/10.1016/j. aucc.2017.07.002.

39. Torres-Contreras CC, Páez-Esteban AN, Hinestrosa-Díaz del Castillo A, Rincón-Romero MK, Amaris-Vega A, Martínez-Patiño JP. Factors associated with delirium in critical patients in a health institution in Bucaramanga, Colombia. Enferm Intensiva. 2019;30(1):13-20. https://doi.org/10.1016/j. enfie.2018.03.003. 
40. Kovács KJ. c-Fos as a transcription factor: a stressful (re)view from a functional map. Neurochem Int. 1998;33(4):287-97. https://doi.org/10.1016/ S0197-0186(98)00023-0.

41. Granberg Axèll AIR, Malmros CW, Bergbom IL, Lundberg DBA. Intensive care unit syndrome/delirium is associated with anemia, drug therapy and duration of ventilation treatment. Acta Anaesthesiol Scand. 2002;46(6):726-31. https://doi.org/10.1034/j.1399-6576.2002.460616.x.

42. Ely EW, Shintani A, Truman B, et al. Delirium as a predictor of mortality in mechanically ventilated patients in the intensive care unit. J Am Med Assoc. 2004;291(14):1753-62. https://doi.org/10.1001/jama.291.14.1753.

43. Peterson JF, Pun BT, Dittus RS, et al. Delirium and its motoric subtypes: a study of 614 critically ill patients. J Am Geriatr Soc. 2006;54(3):479-84. https://doi.org/10.1111/j.1532-5415.2005.00621.x.
44. Balas MC, Deutschman CS, Sullivan-marx EM, Strumpf NE, Alston RP, Richmond TS. Delirium in older patients in surgical intensive care units. J Nurs Scholarsh. 2007;39(2):147-54

45. Lin SM, Da HC, Liu CY, et al. Risk factors for the development of earlyonset delirium and the subsequent clinical outcome in mechanically ventilated patients. J Crit Care. 2008;23(3):372-9. https://doi. org/10.1016/j.jcrc.2006.09.001

\section{Publisher's Note}

Springer Nature remains neutral with regard to jurisdictional claims in published maps and institutional affiliations.
Ready to submit your research? Choose BMC and benefit from:

- fast, convenient online submission

- thorough peer review by experienced researchers in your field

- rapid publication on acceptance

- support for research data, including large and complex data types

- gold Open Access which fosters wider collaboration and increased citations

- maximum visibility for your research: over 100M website views per year

At BMC, research is always in progress.

Learn more biomedcentral.com/submissions 